UNIVERSITY OF CHITRAL JOURNAL OF LINGUISTICS AND LITERATURE

VOL. 2 | ISSUE II | JULY - DEC | 2018

ISSN (E): 2663-1512, ISSN (P): 2617-3611

\title{
A Discourse Analysis of Canadian PM's Speech after New Zealand Christchurch Mosque Shootings
}

\author{
Muhammad Amjad \\ RIPHAH International University Faisalabad \\ mamjadfsd@gmail.com
}

\begin{abstract}
We use language for different purposes that are mostly related to the social practices in different contexts and perspectives. Discourse analysis is one of the disciplines which examines the use of language from different perspectives to reach a possible understanding of the discourse. This paper is also an attempt to analyze language used in a particular context and perspective to understand and expose some constructed realities. The objective of this study is to examine the Canadian PM's moral and ideological standpoint, his commitment to show solidarity with the grieved community, his determination to eradicate terrorism and his linguistic characterization of terrorism that he confirmed in his speech in the House of Common on March 18, 2019 after the Christchurch Mosque Shootings in New Zealand. The analysis is based on Fairclough's conceptions in CDA. It claims that ideologies and texts are interrelated, and it is not possible to break this link between ideologies and texts because the texts can be interpreted in maximum possible ways. This study analyzes the components of ideology and persuasion used in Justin Trudeau's speech to reveal his commitment and persuasive strategies against terrorism, and it gives new hopes to the targeted communities worldwide as well as the general public. He tried to ensure the public that they are not alone because the world leaders and the heads of the states are unconditionally united to eradicate worldwide terrorism.
\end{abstract}

Keywords: CDA, Canadian PM Speech, New Zealand, Christchurch Mosque Shootings

\section{Introduction}

\subsection{Background of the Study}

"CDA is a problem-oriented and multidisciplinary set of theories and methods which have been widely used in educational research" (Rogers, 2011). It is a broad field related to the practical use of language in different contexts and perspectives. It focuses on the social practice of language (Fairclough \& Wodak, 1997), and all forms of social practices are tied to specific historical contexts, demands and functions of social situations, relations and cultures to serve different interests. Moreover, the grammar system of a language is interlinked with the needs of a society and individuals that language is required to serve (Halliday, 1978). "A shared assumption is that discourse can be taken as a multimodal social practice" (Rogers, 2011). The manifold roots of 
CDA focus on different theoretical and methodological approaches, and they have webbed links with different branches of linguistics and "discourse studies have at least seven dimensions in common" (Wodak \& Meyer, 2009).

At present, the study of everyday life, decision-making in organizations and political institutions has become a major new focus of CDA. It also looks into public and political speeches, advertisements, newspapers, official documents and examines the relationship among languages, ideologies and power. Discourse analysts critically study the lexical, syntactical, semantic and pragmatic choices to understand the use of language beyond and behind the text or discourse. Their focus is on constructing or exposing realities by using logical arguments or counter-arguments. Discourse is always meaningful according to different interpretations in different contexts and perspectives. At cohesive level, it is related to textual, formal and structural features, but at coherence level, it is related to the theme, ideas, pragmatic and world knowledge. CDA deals in these two levels. There is a gap of ideas in discourse which we fill with our experience, education, political, economic and social knowledge related to various concepts in an acceptable way. Despite all that, a cohesive text can be uncoherent and a coherent text can be non-cohesive. Coherent text should be attached with the outer world and logical development of ideas should be according to the social practices and world knowledge. Placing the words, phrases, sentences in a different world can change the meaning and interpretation of the same sentence. A sentence in literature, science or in any other area of knowledge will be interpreted differently. The optional elements of world knowledge, moving sequence of events and schemata help to fix the meaning of discourse in different contexts and perspectives.

Among various areas and perspectives of discourse analysis, the theological and ideological issues are very sensitive in every corner of the world, so even a little misunderstanding can cause controversial debates and uncontrollable riots worldwide because these issues are mostly based on emotional interpretations of ideas, traditions and beliefs. Thus, there is a pressing need of time that the thinkers, scholars and research community should play their constructive role to expose the constructed and constructive realities for the people. It is said that failing to address such issues at social, psychological, legal, emotional and ideological levels may cause destructive feedback as recently seen in New Zealand Christchurch Mosque Shootings that can be quoted as an example of a theological or an ideological clash among different groups of a society.

According to the media reports in New Zealand, "the Christchurch Mosque Shootings were two terrorist attacks at the mosques in New Zealand during the Friday Prayer on March $15^{\text {th }}, 2019$. A 28 years Australian white supremacist, as described in media reports, gunman live-broadcasted the first attack in which 50 people were killed and 50 others injured." Politicians and the world leaders condemned the attacks, and PM Jacinda Ardern described it as "one of New Zealand's darkest days." As reported in media, the government has established a royal commission of inquiry into its security agencies on these horrible mass shootings. In this context, Canadian PM Justin Trudeau delivered a speech in the House of Common on March 18, 2019 to condemn these deadly attacks, 
as the global community also condemned the attacks, calling the killer "a monster, a terrorist, a coward motivated by Islamophobia and hateful ideology."

This CDA of Canadian PM Speech on Christchurch Mosque Shootings is of great significance because the MP tries to make his audience believe his words to eradicate terrorism. After quoting some verses from the Quran and the Gospel of Mathew, the PM says that our faith lessons bind us together. He also says that we have seen such tragedies many times before. The world leaders should show their responsibilities to establish peace in every corner of the world. These are the responsibilities that we cannot ignore by simply pointing out the problems and sitting together to talk about them. The PM also urges the heads of the states and the world leaders to come forward and use their maximum resources against terrorism. It is a direct and unanimous message to all terrorists and interest groups that the world is unconditionally united to eradicate terrorism.

\subsection{Significance and Purpose of the Study}

Canadian MP's speech on terrorism after Christchurch Mosque Shootings in New Zealand is very persuasive to assure the world that Canada will do cooperate to the best of its power and economic capacity to eradicate terrorism. The acts of terrorism are the international problems that are very closely related to the theological or the ideological issues, so governments and the world leaders must cooperate to eradicate terrorism. Without their commitment, the world cannot be a safe haven for the coming generations. Undoubtedly, it is a direct message to all the terrorist organizations and interest groups from the world leaders who unconditionally agree to eradicate terrorism. The PM also urges the world leaders to use maximum intellectual, physical and economic resources against terrorism. His words surely give better hopes to the individuals, minorities and the targeted communities because of his commitment to eradicate terrorism and make the world a safe haven for the coming generations. This discourse analysis tries to expose the hidden meanings of the PM's speech on these terrorist attacks. It focuses on developing a clear understanding of the moral and ideological standpoint, commitment and determination of Canadian MP through his speech after Christchurch Mosque Shootings. Moreover, the study will motivate the researchers to investigate and highlight the significance of CDA related to the popular world speeches to understand the thoughts of the world leaders and the international community.

\subsection{Research Questions}

This research study critically analyzes the Canadian MP's Speech after the Christchurch Mosque Shootings focusing on the following research questions.

a) What is the PM's moral and ideological standpoint against terrorism that he wants to show to the world through his speech?

b) What lexical choices and linguistic expressions have been used to show solidarity with the targeted community?

c) What lexical choices and linguistic expressions have been used to show determination to eradicate worldwide terrorism? 
d) How has the PM linguistically characterized the terrorists and the terrorism?

\section{The Review of Literature}

The term discourse has many definitions, and one is that discourse "integrates the whole palettes of meanings" (Titscher et al., 2000). Van Dijk (1998) says CDA is a field that is related to the studies and analysis of written and spoken texts to unfold the discursive sources of power, dominance, inequality and bias. In a similar way, Fairclough (1993) defines CDA as a discourse analysis that aims to systematically explore often opaque relationships of causality and determination between (a) practices, events and texts being discursive, and (b) wider structures of the society and culture, relationship and processes; to look into how such practices, events and texts arise and are ideologically patterned because of the connections of power and struggles. It also explores the relationships between discourse, society, power and hegemony as quoted by Fairclough (1989). Thus, CDA aims at establishing clear connections among discourse practices, social practices and structures which might be unclear to a layperson. The objective of CDA is the use of language as a social practice. Language is an important part of society for social practices and communicative purposes (Fairclough, 1995). The language users do not function in isolation; they function in different structures. CDA accepts all the textual and contextual structures and tries to find out the connections among them, explores the links between structures and their social functions.

CDA of religious, political, ideological and social speeches is of great interest for the international linguistic community to reach an understanding for many different reasons. Researchers are making intellectual efforts to contribute towards various areas of CDA including the analysis of literary texts, newspapers, power, politics and speeches. Many speeches of the well-known political and religious leaders have been critically analyzed by researchers such as Sharififar and Rahmani (2015) analyzed Obama's and Rouhani's speeches at UN, but there is no critical discourse analysis of this speech. This research study is an attempt to contribute to the existing knowledge through the analysis of Canadian PM's Speech. The main analytical tool of our paper is the "three-dimensional method of discourse analysis" introduced by Fairclough namely the language text, written or spoken, discourse practice and the social and cultural practices.

\section{Research Methodology}

The text and video data of the Canadian MP's speech delivered on March 18, 2019 have been taken from $\mathrm{www}$.youtube.com/watch? $\mathrm{v}=\mathrm{I} 2 \mathrm{gwE} 6 \mathrm{PBxIs}$ for this study. Only the qualitative paradigm has been used to understand different perspectives of the speech focusing on the analysis of lexical and syntactical choices, intonation and stress patterns in the speech, the body language of the PM and all kinds of references in the speech to answer the related questions in this particular sociocultural context as stated in (1.3. a-d). For the purpose of CDA of this speech, Fairclough model of "three-dimensional method of discourse analysis" has been chosen. 


\section{Data Analysis}

The data analysis has been done in four subsections focusing on the main ideas in research questions. These subsections are the analysis of ideological standpoint, linguistic devices, lexical choices and linguistic characterization of terrorists.

- Analysis of Ideological Standpoint: Our analysis and interpretations of this speech show its links with international terrorism and the current terrorist attacks in New Zealand. The most important sentences of the PM's speech with critical analysis are stated below to understand the meanings behind the text.

a) "Mr. Speaker, - Before we begin, our hearts go...who are...the aftermath of a tram shooting."

Before discussing some of the main points of his speech about the terrorist attacks at the mosques, the PM expresses his emotions by shedding tears on this tragedy and the significance of its aftereffects. This is a kind of psychological treatment of the grieved families by offering the tearful condolence. The researchers do not call it a political move at the international level to win a kind of favor and popularity among the international community on the bases of humanity. They do not question the sincerity of the PM by looking at his innocently pulled down face shedding tears during his speech among the elected official gathering, but the chances of these political moves and psychological treatment cannot be minimized as it is said that nothing is permanent and impossible is possible in politics. It can be an intentional and deliberate effort to construct another reality and discourse, but positively speaking, his words and the way of tearful condolence are like healing ointment for the emotionally injured people of those grieved communities.

b) "We stand with our Dutch friends ... we will be reaching to out ...offer our ...support."

He shows his great determination to stand with the Dutch friends and reach them to offer all possible supports at that difficult time. It is a short but clear message to the terrorists that the world is united unconditionally on this issue to strongly support the eradication of terrorism in every corner of the world. This is also a kind of persuasion and motivation at the international level, so the other countries and world leaders can come forward for this purpose. In this way, their strong message will not only discourage the terrorists and their organizations but also give a ray of hope to the grieved communities that their future is in the safe hands of the committed leaders.

c) "Mr. Speaker, I rise today to ...deepest condolences to all ... in New Zealand."

Once again, he expresses his deepest and mournful condolence to all the grieving people in New Zealand and the worldwide grieved communities from himself and from the people of his country. The purpose of his speech is to condole with the grieved communities as he mentioned. This is also a psychological therapy of those sad families in New Zealand and in other parts of the world. There is no doubt that love, respect and politeness are very strong antibiotics which can heal the bad injuries, and the PM's healing words do have positive and healing impacts.

d) "Our friends and ... the worst terrorist attack .... An attack ... Islamophobia. Fifty ...murdered ...dozens ...injured. Gunned down ....” 
According to the PM, this is the worst attack in the history of New Zealand in which many friends have suffered. He also declares and links this attack with Islamophobia in which fifty men, women, children and elderly people were murdered during the prayers. There were also many injuries during the shootings. He expresses his anger and feelings of hatred by calling the killer a monster, a terrorist and a coward. His clear message and statement also show that people know, and they should know the reasons of the negative motivation of such hateful people by Islamophobia and such hateful ideology behind such terrorist attacks.

e) "Our hearts ache for mothers and ... who ...chance to say goodbye to their ...."

Once again, he expresses his emotions of painful hearts because fathers, mothers, brothers, sisters, parents and friends will never say goodbye to their relatives whom they love a lot. This is again a psychological therapy at the social relationship level by mentioning the family relationships of people. He is able to create a sense of relationship and bridge the gaps among the grieved families and the world leaders. The hearts-ache, he adds, because of such tragedies; they shake all the human beings even the strangers. The PM hits the nail on the head and catches the attention of the people by talking about these human relationships.

f) "Loved ones killed by a hateful ... who ascribed to a hateful ideology."

Here he touches an important point related to the hateful individual and hateful ideology which cause such problems at the international level. He tries to make people sure that such terrorist attacks are because of the hatefulness in individuals or in their ideologies, and it is very dangerous for our society and can cause such mournful events of killing innocent people for nothing. The world leaders do understand such hateful ideologies behind such killings. That is why, he gives a clear message that such tragedies are because of some individuals from different countries, religions and interest groups. This is also an indirect message that the people from these countries and religions are not of such hateful mentality. They are very peaceful people who are also against such killing of innocent people.

g) "To our Muslim friends here ..., know that we mourn ...you. We feel ...pain,... we love you."

He uses heart-winning words to address the Muslim community in Canada, New Zealand and all over the world that Canadian people also mourn with the Muslims, feel their pain and love them. Such sympathetic attitude and expressions do not let the people be disappointed and turn them to be the hateful individuals having the hateful ideologies because of such targeted, fearful and cruel terrorist attacks.

h) "The Quran tells us: "the true servants of the Most Merciful ... also heard it in the Gospel of Matthew."

These are the historical words of the PM in the speech which will be remembered and quoted for ages. He highlights the importance of peace by quoting the verses from the Quran and the Gospel of Matthew. The Quran teaches its followers to reply with the words of peace when the foolish quarrel with them and the Gospel also speaks of no revenge. Religious motivation, in the positive or negative sense, has no match at any level. The PM uses the religious references very skillfully to convince the people worldwide on the peace issue. It is also a message to the terrorists and their 
organizations that they are not following any religion because the religions do not teach such hateful actions of killing innocent people as he quoted from the revealed books.

i) "Innocent people are killed. Headlines blare out .... It is shameful, and sadly."

Whenever some innocent people are killed in such terrorist attacks, there are different kinds of headlines in the newspapers using different lexical choices to construct some realities. It is also painful to read such words in the papers as "mass shootings, faith-based slaughter and terrorist attack." Such news headlines also cause fear among the nations which are already engaged in a close fight or struggle without weapons. He calls such events shameful and sadly. They are sadly because of the death toll and injuries of innocent people; they injure everyone related to those people. They are also shameful because there are still many people who have debates on such tragedies in different contexts and perspectives, and that we are unable to control them fully.

j) "The leaders ... bear some responsibilities. ...we can ...by simply pointing fingers."

This is another strong statement reminding the world leaders of their responsibilities. He urges the world leaders by reminding them of their responsibilities to play their vital role to eradicate terrorism; this needs some practical steps to resolve such problems. Just talking about these problems and pointing out some problem areas cannot help anyway. He also indirectly criticizes those who just talk about such deadly attacks and do not take part in practical activities against terrorism. It means that responsibility is an integral part of successful life, and people cannot make progress in any sphere of life without it. Then people should not think of resolving such challenging problems without taking their responsibilities seriously.

k) "We see ..., in online harassment... places of worship, acts of violence, and even murder."

He declares, despite all their possible and considerable efforts, that Canada is still facing many security related problems of online harassment and of security at the worship places including violence and killing because of some hateful individuals and ideology. It shows that the Canadian government is observing and addressing such problems at different levels. It is a kind of disappointment to show that Canada is a big country having many resources to eradicate terrorist activities, but the success level is not as high as required or expected by such a resourceful country. Therefore, the world should keep making all its possible efforts to resolve these worldwide problems. If we are united to fight against this worldwide problem despite the lack of resources, we will overcome it, and we will lose if we do not have the intention to do it.

l) "We have seen an increase ...terrorist attacks targeting Muslims...."

This is also an important point that the PM officially mentions about the critical and sympathetic position of the international Muslim communities. The Muslims are being attacked for different reasons all over the world, but some of the countries do not accept this reality because of their own interests. This reference of the PM's Speech in the House of Common can be an authentic quote and a convincing argument of targeting the Muslim all over the world. This is a statement neither of a Muslim leader nor of a layman; it is an official statement by a PM of a secular democratic country which is very closely related to the western countries for its political, religious and economic interests. Thus, it is not possible for the anti-Islamic leaders to reject this statement. This 
is also notable that this statement is not of an individual, but it is a statement by a PM in the presence of all the respectable elected members of the House of Common. This is another heartwining political statement of the PM which convinces the international Muslim community to appreciate him for being a man of principle.

m) “Anti-immigrant hatred, Right-wing extremism, White nationalism, Neo-Nazi terrorism."

After mentioning the targeted attacks at the Muslims all over the world, the PM critically mentions the reasons behind such attacks. He further says that there are a few individuals with such a hateful behavior and ideology who negatively response to the immigrants worldwide. It also shows that this hateful response against the Muslims is from different social groups as he mentions them by their worldwide brand names. These groups are everywhere and in every corner of the world; they are in every sect, religion, social, political and economic interest group.

n) "I am calling on like-minded countries ...in this fight. Muslim, Christian... - we must fight ... as a team."

This is one of the best sentences in the speech that the PM invites all - the Muslims, the Christian, the Jewish, the black and white - all the world to stand with Canada as a team to fight against individual and collective hatred ideology. It should be a team of practical actions to resolve the issues; it is not just thinking and praying after such attacks. The meanings behind the text also show that there are many world leaders and countries that want to work together against this international issue, and there are a few world leaders and countries that have their biased ideologies, so their support is only verbal. Their behavior not only encourages such hateful ideology, but it also encourages practical support from different social, political and religious groups. By calling on the countries for support against terrorism, he stresses on the collective efforts by every social group as a team. It seems that he believes in the collective efforts for success; otherwise, it will not be possible to eradicate this deep-rooted social problem at the international level.

o) "Mr. Speaker, there are ...people than the bad .... We must counter this hatred. And together, we will."

The PM also mentions that the good people are large in numbers as compare to the bad people, so the light will outweighs the dark and the good will outnumber the evil. We must counter this hatred, and we can do it easily when we work together as a team. Without any differentiation among religious and social groups, he mentions that the good people are large in number as compare to the bad people, and it is in every country, region, sect or religion, political, economic and social group. It also shows that the PM wants to take the international community with him to fight against this hateful ideology to eradicate terrorism.

- Analysis of Lexical Choices \& Linguistic Expressions for Solidarity with Effected Community: In this section, lexical choices and linguistic expressions, which show solidarity with the effected community, have been discussed to understand the meanings behind the texts.

a) "We will be reaching out to our counterparts to offer ...support." 
The PM assures an unwavering support to the government in New Zealand as a counterpart. He uses the pronoun ' $w e$ ' to declare that it is not only his point of view to fight against terrorism but also of all the elected members of the present government. They are all unconditionally united to offer their continuous support at all levels against terrorism. Here again he gives a message that all the terrorists and their organizations do cooperate with one another for their hateful ideology to destroy the world peace, so we as the peace keepers and peace makers should also cooperate with one another to establish worldwide peace. Our personal interests should not force us to keep quiet when the innocent people are being attacked and the world peace is being ruined for nothing.

b) "I rise today to express Canada's deepest condolence ... in NZ."

He shows his strong determination to stand with the Dutch friends and reach them to offer all possible physical, intellectual and economic supports at that difficult time. It is also a clear message to the terrorists that the world is united unconditionally to eradicate terrorism from every corner of the world. This is also a kind of persuasion and motivation at the international level, so the other countries and the world leaders should come forward for this purpose. In this way, their strong message will not only discourage the terrorists and their organizations but also give a ray of hope to the targeted communities worldwide that their and their children's future is in the safe hands of the committed leaders. These lexical choices and linguistic expressions show solidarity with the effected communities worldwide.

c) "We mourn with you. We feel your pain, and we love you."

These are also the lexical choices and expressions to show love and solidarity with the grieved community to take part in their moments of sadness and pain. These lexical choices show the PM's concern to realize and feel their pain in such a difficult time. He further adds that all the people in the government and the people of Canada love the Muslims in the country, and they are with them at every step of this difficult time. Here the PM expresses his concerns by simple lexical choices that emotionally attract the grieved communities worldwide.

d) "People are tired of fighting ...of their leaders."

This expression shows that the PM is positively thinking about the people who have been suffering for a long time, and they are still doing all their work regularly and punctually. Such critical conditions could not break their nerves. He appreciates the people who are facing all these problems for a long time without the practical support of their leaders. Before losing their hopes and giving up, we should take our responsibilities to eradicate all kinds of terrorism. If people lose their hopes and stand against their leaders for not taking their responsibilities seriously, no one can stop them, and we can then do nothing to control and face their anger. This situation will strengthen the others to be successful in their purposes. These expressions also force the people to be on the side of the PM despite their dissatisfaction.

e) "We have ... reforms around gun control."

Here he gives a new hope and another assurance to the people saying that the government has taken some strict and meaningful steps related to gun control in the country. It means the government will make it sure that no one can buy, smuggle and carry guns illegally, and it can help to maintain the law and order situations and avoid such mournful tragedies in the future. It 
might be just an idea or beginning of the plan, but it is much more for the public as they are used to construct new hopes on the true or false promises of their political leaders. Thus, it is a better way to show solidarity in such a simple manner.

f) "We increased funding ... places of worship."

To maintain law and order situations in the country, there is a pressing need to allocate huge budgets for training, patrolling, and security agencies of the countries so that they can perform better at all levels. The governments mostly hesitate to allocate huge budgets for such projects which are unseen, but here the PM shows the concerns with the targeted community by mentioning the allocation of huge budgets for security reforms. It is also a kind of effective psychological hook to catch the attention of the public and successfully convince and motivate the people to pay their taxes willingly and happily because these taxes are spent on different projects of public interests including the security of their lives, properties and a happy future of their children.

g) "There are more ... than bad in the world."

He also gives his positive opinion about the people in the world focusing on their interests by these simple lexical choices that also shows his hopes to overcome these problems step by step if it is not possible as quickly as it should be because of the sensitivity of the issue. At this stage, he calls the world for peace distinguishing between the good and bad people. Those who are coming to join the team against terrorism are among the good people and those who are just thinking of their own interests are from the bad people because they focused on their own interests even at the cost of world peace and human lives.

h) All these lexical choices and expressions are heart winning and heart consoling in such a mournful situation where people see the dead bodies of their loved ones. Each of his words is like some healing ointment for aching hearts of the grieving families and friends. The PM not only expresses his deepest condolence to the grieving families but also shows his pain and love for them. He uses the words such as unwavering support, deepest condolence, grieving, heart ache, mothers, fathers, sisters, brothers, parents and friends, mourn, pain, love, responsibility, maintain freedom, meaningful reforms, gun control, increase funding, security at places of worship, much more to do and more good people than bad people. All these lexical choices express the deepest emotions, sympathy and solidarity of the PM with the targeted communities in the world.

- Analysis of Lexical Choices \& Linguistic Expressions Used to Show the Eradication of Terrorism: These lexical choices and linguistic expressions of the PM show his determination to eradicate worldwide terrorism.

a) "The leaders ... bear some responsibility. ...can no longer ignore simply pointing fingers." He shows his determination to eradicate terrorism by calling on the world leaders to realize their responsibility. Without this realization, it will not be possible to see a peaceful world. Those who bear responsibilities are among us and those who think about their interests are others who prefer their own interests even at the cost of world peace and human lives. This is also a worldwide message that there are world leaders and countries that are not taking their responsibilities seriously to give a safe and better future to the coming generations. It is a kind of hook to convince the 
people in favor of the policies of the present government because the government is thinking of the better future of the coming generations.

b) "We cannot let ... these 50 deaths unlearned."

Here the PM indirectly mentions taking strict actions against the terrorists who are killing the innocent people. The lesson of these 50 deaths must not be left unlearnt this time. It is all because human lives are very precious on the earth, and nothing is more important than this. Thus, those who commit crimes against humanity must be punished and let them be an example for those who do not cooperate with us to establish peace in the world. Nothing is more important for us than the lives and prosperity of our people in the world. The PM again speaks about what people are thinking using very simple words and expressions.

c) "We can take a stand...in Canada and around ..., and say ... is enough."

He mentions that we should not bear such losses anymore and give some crushing reply saying that enough is enough. If we do not do it now, we cannot stop the international terrorism anywhere. There is a limit for every human being to bear such things. If we do not say that enough is enough, the world community will say it, and then we do not have any choice to control things. This sentence also shows the anger of the PM because some countries are not taking their responsibilities seriously. He wants the international community to take up this issue seriously for the grand interests of their people as well as for the coming generations.

d) "We will do what need .... And we will bring this message ...stage."

Here the PM promises with the people that the government will do what is needed at every level and will also be able to bring this message at the international level for better hopes in the future. On one hand, people are cooperating with their governments and the world leaders, and they are looking at them for some decisive results. On the other hand, the governments and the world leaders are still thinking of their long term interests. If the world does not take up these issues as suggested and recommended, we will keep experiencing such horrible tragedies of death traps and tolls somewhere in the world.

e) "The fight against racism and ... fight. But we can't put it off anyway."

He further says that there are different context and perspectives of this issue, so we have to fight against this hateful ideology whenever and wherever we find it without thinking of our personal and national interests because human lives are more important. We have to do it for humanity. If we fan the flame now because of our interests, we cannot save our own home from the upcoming fatal accidents. There is no other and better way to eradicate terrorism if we control racism and discrimination either through table talks or else. To engage these people of hateful ideology to come to the table for dialogue is also a kind of fight at psychological and ideological levels to eradicate worldwide terrorism. It is only possible if we decide to do it keeping away the national ego, pride of strong military power and selected snobberies.

f) "We must counter this hatred. And together, we will."

All these lexical choices and expressions show the determination and strong will-power of the PM to eradicate the international terrorism. He calls on all the international leaders to come forward and stand with the Canadian government, and his words show his determination to resolve such 
hateful issues at the individual and the ideological levels. The PM tries to show a better and peaceful future to people and their children where everyone will live peacefully, and people will not be attacked because of their faith and ideology. The PM uses the words such as unwavering support, responsibility, take a stand, enough is enough, call on countries to stand with Canada, fight as a team, investigations into extreme hate groups, fight against racism and intolerance and can't put it off. All these words show the PM's determination and unwavering support to eradicate terrorism all over the world.

- Analysis of Linguistic Characterization for Terrorism: The PM uses very strong words for the linguistic characterization of terrorists which show the anger and determination of the world leaders against terrorists and terrorism.

a) These lexical choices and linguistic expressions for characterization of terrorism show the negative denotative and connotative meanings in a broad perspective. The words have been chosen from different contexts. He not only uses words of negative meanings but also the words which represent different extremist groups in different religions and societies. These terrorist groups are active in different parts of the world, so he uses the words which are mostly used by the international electronic and print media for different kinds of worldwide terrorist attacks.

b) He uses the words such as the worst terrorist attack, attack motivated by Islamophobia, gunned down by a monster, a coward, the hateful individuals and ideology, the mass shooting, the faithbased slaughter, the shameful, anti-Semitic, anti-black, anti-indigenous, anti-immigrant, the Rightwing extremism, the White nationalism, Neo-Nazi terrorism, Daesh, Al-Qaida and Boko Haram. These lexical choices and expressions represent different social, religious, ideological and hateful classes or interest groups worldwide. They have their own ideology of the right and wrong, the religious tolerance or dialogues for peace in the world. By his linguistic and lexical choices, the PM touches every ideological corner related to different social groups which are involved in worldwide terrorist activities.

c) There are also many important linguistic features of the speech which need analysis from different perspectives. The PM uses many incomplete sentences, incomplete phrases and even words to express his ideological standpoint and the concern of the Canadian government. In this style of real-life discourse, he uses anaphoric and cataphoric references, transitional words for cohesive devices, logical development of ideas as a coherence device, unity and many other linguistic features. The co-text, which he uses in the main text of speech, helps the readers to fully understand the context of his speech. All these verbal and nonverbal expressions and features elaborate his chosen words, phrases and sentences in their context and perspective for better understanding.

\section{Findings}

a) The PM selected very simple and impressive lexical choices and linguistic expressions to convey his standpoint against terrorism and convince the Muslim communities worldwide by offering his full support to eradicate terrorism for the better future of the coming generations. 
b) He urged the international leaders and countries to take their responsibilities seriously instead of just talking about these problems.

c) He also used some peace references from the Quran and the Gospel to convince people against terrorism, and it is a message to the terrorists that they are not following any religion because a religion does not allow killing of innocent people for any reason.

d) He called all terrorist organizations worldwide by their brand names indicating their negative roles of destroying the world peace for their personal interests even at the cost of human lives. He used negatively strong lexical choices for the terrorist who attacked the Christchurch Mosques in New Zealand.

e) The PM also hooked people by talking about human relations, their importance in life and the human emotions for which people can do everything.

f) He successfully convinced and assured the people about the better future of the coming generations because the world leaders are unconditionally united to eradicate worldwide terrorism.

\section{Conclusion}

Discourse analysis is a broad field that is related to the practical use of language in different contexts and perspectives. It focuses on language as a social practice and all forms of social practices are linked to particular historical contexts, demands and functions of social situations, relations and cultures to serve different interests and purposes. After going through the different stages and contexts of this discourse analysis of the Canadian PM's Speech in the House of Common on March 18, 2019 after the Christchurch Mosque Shootings in New Zealand, the researchers have come to the conclusion that the PM very successfully elaborated his moral and ideological standpoint against terrorism. He showed solidarity with the targeted community through his best lexical choices, linguistic expressions and his determination to eradicate worldwide terrorism. He openly mentions the terrorist organizations one by one by their brand names and invites the international community to stand with Canadian government to address these issues at different levels instead of pointing these problems with fingers only. This can only be successfully done when we work and fight all together as a team for the prosperity and better future of the coming generation.

\section{Reference}

Canadian PM's Speech (2019). www.youtube.com/watch?v=I2gwE6PBxIs

Dijk, T. A. (1998). Ideology and discourse. Barcelona: Pompeu Fabra University. Retrieved from http://www.discourses.org/UnpublishedArticles/Ideology\%20and\%20discourse.pdf

Fairclough, N. (1989). Language and power. London: Longman Publishing Fairclough, N. (1993). Discourse and social change. Cambridge: Blackwell Publishing Fairclough, N. (1995). Critical discourse analysis: the critical study of language. London: Longman Publisher 
Fairclough, N., \& Wodak, R. (1997). Critical discourse analysis, in T.A. van Dijk (ed.) Discourse as Social Interaction. London: Sage, 258-284

Halliday, M. (1978). Language as social semiotics: The social interpretation of language and meaning. London: Edward Arnold

Rogers, R. (2011). An introduction to critical discourse analysis (Second. Ed). London: Routledge

Sharififar, M., \& Rahimi, E. (2015). Critical discourse analysis of political speeches: A case study of Obama's and Rouhani's speeches at UN. Theory and Practice in Language Studies, 5 (2), 343 - 349

Titscher, S., Meyer, M.; Wodak, R.; \& Vetter, E. (2000) Methods of text and discourse analysis. London: Sage.

Wodak, R., \& Mayer, M. (2009). Critical discourse analysis: History, agenda, theory and methodology 1. Retrieved from https://www.researchgate.net/publication/265678850

\begin{tabular}{|l|l|l|}
\hline CC) 2017 by the author. Licensee University of Chitral, Journal of Linguistics \& \\
Literature, Pakistan. This article is an open access article distributed under the \\
terms and conditions of the Creative Commons Attribution (CC BY) \\
(http://creativecommons.org/licenses/by/4.0/).
\end{tabular}

